Т. В. Сандуляк, Т. М. Клименко, О. А. Сердцева, О. Ю. Карапетян, А. М. Закревський, М. Т. Сандуляк Харківська медична академія післядипломної освіти

\title{
ЯК ПОДОЛАТИ НЕДОСТАТНЮ МОВНУ ТА ЦИФРОВУ КОМПЕТЕНТНОСТІ ВИКЛАДАЧІВ І СЛУХАЧІВ У ПІСЛЯДИПЛОМНІЙ ОСВІТІ
}

\section{T. V. Sandulyak, T. M. Klimenko, O. A. Serdtseva, O. Yu. Carapetyan, A. M. Zakrevskiy, M. T. Sandulyak Kharkiv Medical Academy of Postgraduate Education \\ HOW TO OVERCOME INSUFFICIENT LANGUAGE AND DIGITAL COMPETENCES OF TEACHERS AND STUDENTS IN POSTGRADUATE EDUCATION}

\begin{abstract}
Мета роботи - окреслити сучасні компетенції лікаря-неонатолога по формуванню здорового початку нового життя та веденню періоду новонародженості й запропонувати резерви покращення післядипломної підготовки спеціалістів і фахівців зі спеціальності “Неонатологія” шляхом засвоєння оновлених і доповнених у 2017-2018 рр. ключових компетентностей - мовної, цифрової та фахової.

Основна частина. Розглядаються суть, зміст оновленої у 2017 р. цифрової та мовної компетентності, їх вплив на формування фахово-професійної компетентності та нові компетенції викладачів і слухачів за рівнями Європейської рамки кваліфікацій та ключовими компетентностями для безперервного навчання впродовж життя, рекомендованими Європейським парламентом $\mathrm{i}$ Радою ЄС у 2018 р.

Проаналізовано причини недостатньої мовної та цифрової компетентності викладачів і слухачів курсів післядипломної освіти та користувачів систем електронної освіти і медицини, показано, що без відповідного рівня володіння мовною компетентністю - знання англійської мови на рівні В2 за шкалою Common European Framework of Reference for Languages неможливо адекватно засвоїти цифрові технології, набути необхідної цифрової та професійної компетентності. Зроблено висновки щодо подолання мовної та цифрової нерівності викладачів і слухачів та необхідності підготовки кадрів у рамці нових сучасних компетенцій слухачів.

Висновки. Таким чином, формування сучасних компетентностей з неонатології, зважаючи на важливість для суспільства фахових компетенцій та результатів діяльності неонатологів і суміжних спеціалістів, слід проводити на циклі тематичного удосконалення “Адаптація та патологія новонароджених” тривалістю не менше 1 міс. Навчально-тематичний план навчання на цьому циклі необхідно доповнити новими компетентностями для досягнення сучасного рівня компетенцій спеціалістів $\mathrm{i}$ фахівців з неонатології.
\end{abstract}

Ключові слова: цифрова та мовна компетентність викладача і слухача; цифрова нерівність; післядипломна професійна освіта; нові компетенції викладача і слухача.

The aim of the work - to outline the modern competencies of the neonatologist on the formation of a healthy start of a new life and the management of the newborn period, and to offer the reserves for the improvement of postgraduate training of specialists and specialists in the specialty of Neonatology by assimilating key competences updated and supplemented in 2017-2018 - language, digital and professional

The main body. The essence, content of the digital and linguistic competence updated in 2017, their influence on the formation of professional and professional competence and new competences of teachers and students on the levels of the European Qualifications Framework and the key competences for lifelong learning recommended by the European Parliament and the EU Council in 2018 are considered.

The reasons of lack of language and digital competency of teachers and students of postgraduate education and users of electronic education and medicine systems have been analyzed, it is shown that without proper level of language competence, knowledge of English at level B2 can not be adequately assimilated by digital technology, to acquire the necessary digital and professional competence. Conclusions have been made to overcome the linguistic and digital inequality of teachers and students and the need for training in the framework of new modern competencies of students.

Conclusions. Thus, the formation of modern competencies in neonatology, taking into account the importance for the society of professional competences and outcomes of neonatologists and adjacent specialists, should be carried out in the thematic improvement

(c) Т. В. Сандуляк, Т. М. Клименко, О. А. Сердцева та ін. 
the cycle of Adaptation and Pathology of Newborns of at least 1 month duration. The training curriculum in this cycle needs to be supplemented with new competencies to achieve the current level of competencies of specialists and neonatology specialists.

Key words: digital competence of faculty and students; digital divide; postgraduate professional education; new competences of faculty and postgraduate students.

Вступ. Професійна діяльність лікаря є одночасно процесом, механізмом і результатом прояву фахово-професійної компетентності [6] та спроможність виконати покладені на нього обов'язки в межах відведених компетенцій за фахом і посадою. Діяльність неонатолога поєднує досвід, знання, вміння, сумлінне дотримання етичних норм, поведінкові реакції та ставлення - автономність і відповідальність (здатність самостійно виконувати завдання, розв'язувати задачі і проблеми та відповідати за результати своєї роботи). Компетентність - об'єктивна оціночна категорія, суспільно визнаний рівень знань, умінь, навичок, що дозволяє особистості виконувати певні дії через власне ставлення. Компетенція - параметр соціальної ролі лікаря, що поєднує його фахову підготовку та готовність до мобілізації знань, умінь, зовнішніх ресурсів для ефективної діяльності в конкретній професійній ситуації задля якісного продуктивного виконання поставленої задачі і отримання соціально закріпленого результату або заданої соціальної норми [5]. В нашій країні термін “компетенція” (від лат. compete - відповідати, підходити) сприймають як коло повноважень, наданих посадовій особі законом, статутом або іншим актом, для виконання яких їй потрібні знання і досвід у певній галузі [5]. Компетентності набувають у навчанні, а компетенції регламентуються атестацією і ліцензіями на право медичної діяльності після отримання відповідного рівня знань, вмінь i досвіду роботи, підтвердженого сертифікатами про володіння ключовими компетентностями. Тобто зміст і межі компетенцій для спеціаліста і фахівця визначені наперед, а при навчанні й атестації спеціаліста та фахівця перевіряється досягнення ними необхідного рівня компетентностей, щоб відповідати професійно-посадовим вимогам і бути здатним до виконання заданої роботи за фахом і займаною посадою відповідно до стандартів і нових протоколів профілактики, діагностики та лікування [3].

Мета роботи - окреслити сучасні компетенції лікаря-неонатолога по формуванню здорового початку нового життя та веденню періоду новонародженості й запропонувати резерви покращення післядипломної підготовки спеціалістів і фахівців зі спеціальності “Неонатологія” шляхом засвоєння оновлених і доповнених у 2017-2018 рр. ключових компетентностей - мовної [1, 9], цифрової [8, 10] та фахової [3].

Основна частина. Формування фахової компетентності неонатолога на кафедрі неонатології ХМАПО - процес закономірної послідовної і цілеспрямованої зміни в змісті, структурі післядипломної медичної освіти, що розпочинається в інтернатурі і триває упродовж усього життя відповідно до вимог оновлених Європейської рамки кваліфікацій (ЄРК) (2017) [7] та ключових компетентностей, рекомендованих Європейським парламентом і Радою ЄС $[8,10]$ у 2018 р. Мета післядипломного навчання - передбачуване та цілеспрямоване застосування знань, умінь та набуття інтегральної компетентності на 7-8 рівні за Національною рамкою кваліфікацій (НРК) [4] в контексті Закону України “Про вищу освіту” [1, 2].

Компетенції лікарів з неонатології змінюються відповідно до вимог часу і рівня розвитку перинатології та медицини у світі та державі. Викладачі закладів післядипломної освіти мають мати експертний (науковий) рівень своєї професійної компетентності, щоб володіти, прописати в програмах і впроваджувати в процесі навчання ті компетентності спеціаліста та фахівця, які дозволять неонатологу отримати соціально гарантований, заданий в межах компетенцій фахівця, результат якості надання медичної допомоги. В умовах впровадження сучасних перинатальних технологій та стандартів виходжування новонароджених, основаних на даних доказової медицини та належної клінічної практики, на кафедрі неонатології ХМАПО створюються нові програми і сучасна навчально-методична база. Навчальні програми циклів орієнтовані на кожному занятті на досягнення спеціалістами і фахівцями необхідних фахових компетентностей шляхом створення ефективних механізмів запровадження компетентнісного підходу і отримання заданого результату - досягнення слухачами певних рівнів компетенцій. Але цьому процесу суттєво заважає брак у лікарів, слухачів і викладачів відповідної мовної та цифрової компетентності.

В Україні немає дипломної підготовки неонатолога. Спеціалістів і фахівців готують заклади післядипломної освіти з числа педіатрів. На відміну від підготовки фахівців інших спеціальностей, де слу- 
хачі мають відповідний базовий рівень знань і вмінь та продовжують нарощувати спеціальні професійні компетентності, в неонатології потрібно спочатку “створити” спеціаліста, а вже потім з нього формувати фахівця. За короткий період навчання спеціаліста (3 місяці) це під силу тільки викладачам 3 фаховою підготовкою на високому науковому або експертному рівні, котрі мають відповідну мовну[1, 9] і цифрову компетентності [10] і використовують ïx у підготовці навчально-методичних матеріалів та інтерактивному навчанні.

Мовна компетентність викладача в Україні зафіксована згідно з постановою КМУ від 19.08.2015 р. № 656 “Про деякі питання реалізації статті 54 Закону України “Про вищу освіту” [1]. 31 січня 2016 р. введений у дію новий порядок затвердження рішень про присвоєння вчених звань. Відповідно до урядової постанови, вчене звання професора, доцента або старшого дослідника присвоюватиметься працівникам вищих навчальних закладів та наукових установ, які мають сертифікат мовної освіти на рівні В2 за шкалою Загальноєвропейських рекомендацій з мовної освіти [7]. Сутність інноваційної складової в змісті іншомовної підготовки викладачів необхідно змінювати відповідно вимог доповнених рекомендацій.

Цифрова компетентність - знання, вміння і навички критично та відповідально використовувати та взаємодіяти з цифровими технологіями для навчання, роботи, участі у проектах суспільства, громади, закладу. Цифрова компетентність включає інформаційну і технологічну грамотність (комунікація та співпраця, створення цифрового контенту та програмування), медіа-грамотність, безпеку і кібербезпеку, власне цифрове благополуччя та розв’язання проблем на високому рівні [8, 10]. Лікарі повинні критично підходити до достовірності, надійності i впливу інформації та фактологічних даних, що доступні цифровими засобами для всіх, і усвідомлювати юридичні та етичні принципи, пов’язані 3 використанням цифрових технологій для співпраці з іншими і досягнення особистих, колективних і соціальних цілей. Викладачі повинні вміти керувати інформацією та її вмістом для конкретних проектів, захищати власні дані та цифрові ідентичності, а також визнавати та ефективно працювати з програмами, пристроями, штучним інтелектом та роботами для симуляційного і дистанційного навчання [8].

Фахова компетентність сучасного викладача в неонатології - це поєднання високого або експертного рівня знань і вмінь зі спеціальності та спро- можність як педагога до використання особистісно-орієнтованого підходу в якості нової парадигми освіти й виховання; це можливості діагностувати та швидко змінювати цілі індивідуального навчання спеціалістів і фахівців, вміння підібрати зміст, принципи і технології навчання для кожного слухача; це вільне володіння інформаційно-комунікаційними технологіями, рідною та англійською мовами, юридична обізнаність, самостійність і відповідальність. Такий викладач не народжується в природі, а виховується в освітньому середовищі навчального закладу та в оточенні на кафедрі.

3 відміною в Україні національних уніфікованих клінічних протоколів і введенням переліку настанов і міжнародних стандартів [3], розроблених національними та/або фаховими медичними асоціаціями країн-членів ЄС, США, Канади та Австралійського Союзу на основі доказової медицини і належної клінічної практики, викладені англійською мовою та/або українською (у перекладі), суттєво змінились компетенції лікарів і виросли вимоги до мовної та цифрової компетентності лікарів, слухачів циклів післядипломного навчання та викладачів. Для користування вказаними новими протоколами необхідний рівень знання англійської мови не менше В2 за шкалою Common European Framework of Reference for Languages [9] - може розуміти зміст і основні ідеї тексту на конкретну тему за своїм фахом і повноцінно перекласти та (або) переказати його рідною мовою. Більше того, батьки дитини та пацієнти старше 18 років повинні дати інформовану згоду на проведення діагностики і лікування за обраними лікарем протоколами, котрі необхідно розтлумачити батькам дитини в межах юридичної норми і відповідальності лікаря, закладу і батьків за результати проведеного лікування. Без зазначеного рівня володіння англійською мовою як викладачами, так і слухачами неможливо ефективно оволодіти цифровою компетентністю, користуватися новою інформацією та безперервно набувати професійного досвіду для зростання фахово-професійної компетентності, а також для грамотного використання в Україні міжнародних стандартів діагностики та лікування, впровадження електронної освіти та медицини.

При направленні інтернів та педіатрів для спеціалізації на кафедрі неонатології передбачається, що вони вже володіють базовими компетентностями з педіатрії та неонатології на 5-7 рівні за НРК [4] - здатні розв’ язувати типові спеціалізовані задачі в певній галузі професійної діяльності або у 
процесі навчання, застосовувати положення і методи відповідної науки і характеризується певною невизначеністю умов, а після навчання - зможуть розв’язувати також і складні задачі, до яких відносяться проблеми надання допомоги новонародженим. Але на практиці це не так, викладачам доводиться формувати елементарні і базові знання та вміння, а вже потім, на їх базі - навчати розв’язувати типові і складні завдання. Звісно, що за період навчання на кафедрі неонатології справитись із таким завданням на заданому рівні якості складно, не всі слухачі здатні до такого інформаційного навантаження і подальшого навчання та розвитку. Оскільки програма навчання і фахова кваліфікація неонатолога охоплюють кілька галузей медицини, котрі відносяться до категорії міждисциплінарних, вважаємо за потрібне на методичній нараді фахівців MO3, опорної та кафедр неонатології, педіатрії та неонатології, перинатальної медицини і медичної генетики описати інтегральну компетентність - узагальнений опис кваліфікаційного рівня фахівця зі спеціальності “Неонатологія”, який виражає основні компетентності та характеристики рівня компетенцій щодо навчання та професійної діяльності, а вже потім обрати методи інтерактивного навчання спеціаліста і фахівця і переглядати їх кожні 5 років за результатами атестації.

Інноваційні освітянські технології в підготовці неонатологів на кафедрі передбачають набуття таких фахових компетенцій, як: здатність від початку професійної діяльності розуміти та оцінювати вікові (гестаційні і календарні) особливості адаптації та патології новонароджених; бути готовим надати їм необхідну екстрену, невідкладну та планову медичну допомогу за прийнятими в державі новими стандартами і протоколами; організувати соціальну допомогу нужденним і навчати батьків дитини методів розвиваючого догляду, контролю за розвитком малюка, забезпечення раціонального харчування та ефективного імунного захисту, створення безпечного середовища зростання і виховання здорового способу життя, а також визначення потреби та обрання маршрутів диспансеризації хворих новонароджених і передчасно народжених дітей перших місяців життя з вродженою і перинатальною патологією для їх подальшого катамнестичного спостереження.

Компетентнісний підхід і результатна парадигма в освіті розглядають початок нового життя не з першого подиху новонародженого, а з усвідомленого бажання батьків мати здорову дитину і планування вагітності під контролем сімейного лікаря за їх станом здоров’я. Для оздоровлення майбутніх батьків потрібна постійна співпраця зі спеціалістами задля інтегрованого ведення жінок і чоловіків репродуктивного віку з обтяженим анамнезом, генетичною схильністю та проявами соматичної, психічної, гінекологічної та іншої патології. Потрібна консолідація компетенцій та зусиль неонатологів і суміжних спеціалістів перинатальних центрів у формуванні таких груп ризику та їх обов’язковому подальшому обліку в кабінетах планування сім’ї жіночих консультацій. Поки що така компетенція неонатолога очікувана, але не прописана юридично. Виписки хворих дітей не містять відповідних рекомендації по оздоровленню сім’ї. Відповідно, планування вагітності і догравідарна підготовка проводиться лише в третині сімей, що iї потребують. Немає окресленої компетенції неонатолога щодо співпраці з сімейним лікарем для спостереження за вагітною групи перинатального ризику за результатами попереднього народження хворої дитини. Відповідно скерування до спеціалістів, динамічна оцінка та аналіз результатів спостереження, попередня підготовка до пологів та інші компетенції сімейного лікаря або не виконуються, або формально оформляються терапевтом, ендокринологом, іншими спеціалістами без їх відповідальності за кінцевий результат надання якісної, ефективної медичної допомоги - народження здорової дитини.

Огляд немовляти після виписки з пологового стаціонару або домашніх родів, ведення періоду новонародженості чітко описані у відповідних настановах, протоколах і наказах МОЗ України, але з точки зору нової парадигми організації охорони громадського здоров’ я - предиктивна, превентивна та персоналізована медицина (4P), слід уточнити і конкретизувати роль неонатолога, сімейного лікаря та інших суміжних спеціалістів і навчити їх методик оцінки стану здоров’я новонароджених i обрання ресурсу надання планової допомоги дітям раннього віку. Диспансеризація новонароджених та передчасно народжених дітей раннього віку з вродженою та перинатальною патологією та подальше їх катамнестичне спостереження також потребує пояснення суті та структури нових компетенцій лікарів-неонатологів і суміжних спеціалістів, їх ретельної підготовки з патології новонароджених і розвитку недоношених дітей.

Таким чином, формування сучасних компетентностей з неонатології, зважаючи на важливість для суспільства фахових компетенцій та результатів 
діяльності неонатологів і суміжних спеціалістів, слід проводити на циклі тематичного удосконалення “Адаптація та патологія новонароджених” тривалістю не менше 1 міс. Навчально-тематичний план навчання на цьому циклі необхідно доповнити новими компетентностями для досягнення сучасного рівня компетенцій спеціалістів і фахівців 3 неонатології.

Висновки. 1. Для ліквідації невідповідності мовної та цифрової компетентності лікарів, слухачів і викладачів їх фахово-професійній підготовці і досвіду роботи потрібно об’єднати зусилля навчальних закладів, громад і держави у створенні відповідних інституцій, фінансованих програм навчання працюючих фахівців і викладачів та підготовки майбутніх працівників.

2. Формування освітніх програм спеціалізації та фахової підготовки неонатологів є колективною справою спеціалістів МОЗ і викладачів опорної та кафедр неонатології закладів післядипломної підготовки. Рекомендуємо переглянути і доповнити зміст і структуру навчання з неонатології для досягнення компетенцій за вимогами ЄРК.

\section{Список літератури}

1. Деякі питання реалізації статті 54 Закону України “Про вищу освіту” : Постанова КМУ від 19 серпня 2015 p. № 656. - Режим доступу : http://zakon2.rada.gov. ua/laws/show/656-2015-\%D0\%BF.

2. Про вищу освіту : Закон України від 01.07.2014 р. № 1556-VII (редакція від 01.01.2018 р.) // Відомості Верховної Ради. - 2014. - № 37-38. - С. 2004. - Режим доступу : http://zakon2.rada.gov.ua/laws/show/1556-18.

3. Про внесення змін до наказу Міністерства охорони здоров’я України від 28 вересня 2012 р. № 751 : наказ МО3 України від 29.12.1016 р. № 1422. - Режим доступу : http://zakon2.rada.gov.ua/laws/show/z0530-.

4. Про затвердження Національної рамки кваліфікацій : Постанова КМУ від 23 листопада 2011 р. № 1341. - Режим доступу : http://zakon3.rada.gov.ua/laws/ show/1341-2011-\%D0\%BF.

5. Професійно-педагогічна компетентність викладача вищого навчального закладу : навч. посіб. / за ред. І. Л. Холковської. - Вінниця : ТОВ “Нілан ЛТД”, 2017. - 144 с.

6. Хоменко К. П. Формування професійної компетентності майбутніх лікарів в університетах Польщі (19902015) : дис. на здобуття наук. ступеня канд. пед. наук / К. П. Хоменко. - К., 2017. - 216 с.

\section{References}

1. Deiaki pytannia realizatsii statti 54 Zakonu Ukrainy "Pro vyshchu osvitu" [Some issues of the implementation of Article 54 of the Law of Ukraine On Higher Education].
3. На методичній нараді викладачів опорної та суміжних кафедр, що навчають спеціалістів і фахівців 3 неонатології на курсах підвищення кваліфікації, необхідно узгодити зміст і структуру навчання за сучасними вимогами 4Р медицини та рекомендацій ЄС 2018 р. щодо ключових компетентностей мовної і цифрової.

4. Для подолання цифрової нерівності викладачів і слухачів необхідно: а) вивчити англійську мову на рівні В2 на курсах підвищення кваліфікації 3 англійської мови професійного спрямування для лікарів і викладачів за вимогами уряду; б) створити програми цифрової підготовки викладачів і слухачів на курсах тематичного удосконалення за рівнями оволодіння цифровою компетентністю відповідно до рекомендацій ЄС 2017 р. та оновлених ключових компетентностей для навчання впродовж життя 2018 р.; в) розпочати вивчення настанов і нових протоколів діагностики та лікування мовою оригінала (англійською) на профільних кафедрах відповідно до нових компетенцій лікарів-неонатологів за фахом і посадою, що виникли у 2018 р.

7. Council recommendation of 22 May 2017 on the European Qualifications Framework for lifelong learning and repealing the recommendation of the European Parliament and of the Council of 23 April 2008 on the establishment of the European Qualifications Framework for lifelong learning / Official Journal of the European Union [internet]. - 2017. Vol. 60. - P. 15-28. Available at : https://publications.europa. eu/en/publication-detail/-/publication/ceead970-518f-11e7a5ca-01aa75ed71a1/language-en.

8. Carretero S. The digital competence framework for citizens with eight proficiency levels and examples of use / S. Carretero, R. Vuorikari, Y. Punie. - 2017. - 48 p. DOI : 10.2760/38842.

9. Carretero S. Common European framework of reference for languages: Learning, teaching, assessment companion volume with new descriptors / S. Carretero, R. Vuorikari, Y. Punie. - 2018. - 235 p. Avaliable at : https:// rm.coe.int/cefr-companion-volume-with-new-descriptors-2018/1680787989.

10. Proposal for a council recommendation on key competences for life long learning. 2018/0008 (NLE). - Brussels, 2018. - 18 p. - Available at : https://ec.europa.eu/education/ sites/education/files/recommendation-key-competenceslifelong-learning.pdf.

Postanova № 656 KMU vid 19 serpnia 2015 r. Retrieved from: http://zakon2.rada.gov.ua/laws/show/656-2015\%D0\%BF [in Ukrainian]. 
2. Zakon Ukrainy Pro vyshchu osvitu vid 01.07.2014 r. № 1556-VII, st 54 (redaktsiia vid 01.01.2018) [Higher Education Act of Ukraine as of 01.07.2014, № 1556-VII, p. 54 (edited as of 01.01.2018)]. Vidomosti Verkhovnoi Rady Verhovna Rada of Ukraine Bulletin, 37-38. Retrieved from: http://zakon2.rada.gov.ua/laws/show/1556-18 [in Ukrainian].

3. Nakaz MOZ Ukrainy vid 29.12.1016 r. № 1422 Pro vnesennia zmin do nakazu Ministerstva okhorony zdorovia Ukrainy vid 28 veresnia 2012 roku № 751[On Amendments to the Order of the Ministry of Health of Ukraine as of September 28, 2012 No. 751]. Retrieved from: http://zakon2. rada.gov.ua/laws/show/z0530- [in Ukrainian].

4. Pro zatverdzhennia Natsionalnoi ramky kvalifikatsii [On approval of the National Qualifications Framework]. Postanova № 1341 KMU vid 23 lystopada 2011 r. Resolution of the Cabinet of Ministers of Ukraine № 1341 as of 23.11.2011. Retrieved from: http://zakon3.rada.gov.ua/ laws/show/1341-2011-\%D0\%BF [in Ukrainian].

5. Kholkovska, I.L. (Ed.). (2017). Profesiino-pedahohichna kompetentnist vykladacha vyshchoho navchalnoho zakladu: navch. posibnyk [Professional and pedagogical competence of a teacher of a higher educational institution: teaching. manual]. Vinnytsia: TOV "Nilan LTD” [in Ukrainian].

6. Khomenko, K.P. (2017). Formuvannia profesiinoi kompetentnosti maibutnikh likariv v universytetakh Polshchi (1990-2015) [Formation of professional com- petence of future doctors in universities of Poland (1990-2015)]. Candidate's thesis. Kyiv. Retrieved from: http://ihed.org.ua/images/doc/ogoloshenya_pro_zahisti/ Homenko_08.06.2017_disertac.pdf [in Ukrainian].

7. (2017). Council recommendation of 22 May 2017 on the European Qualifications Framework for lifelong learning and repealing the recommendation of the European Parliament and of the Council of 23 April 2008 on the establishment of the European Qualifications Framework for lifelong learning. Official Journal of the European Union, 60, 15-28. Retrieved from: https://publications.europa.eu/en/ publication-detail/-/publication/ceead970-518f-11e7-a5ca01aa75ed71a1/language-en.

8. Carretero, S., Vuorikari, R., \& Punie, Y. (2017). The digital competence framework for citizens with eight proficiency levels and examples of use. DOI :10.2760/38842.

9. Carretero, S., Vuorikari, R., \& Punie, Y. (2018). Common European Framework of Reference for Languages: Learning, Teaching, Assessment Companion Volume with New Descriptors. Retrieved from: https://rm.coe.int/cefr-companion-volume-with-newdescriptors-2018/1680787989.

10. (2018). Proposal for a council recommendation on key competences for life long learning. 2018/0008 (NLE). Brussels. Retrieved from: https://ec.europa.eu/education/ sites/education/files/recommendation-key-competenceslifelong-learning.pdf.

Електронна адреса для листування: todorsandulyak@gmail.com

Отримано 20.07.18 